\title{
ASSET IMPAIRMENT AND EARNINGS MANAGEMENT: INFLUENCE OF AUDIT QUALITY
}

\author{
Sandra Alves \\ University of Aveiro, Portugal
}

\begin{abstract}
Dortuguese listed firms (as well as all EU companies) have been required to use IFRS and consequently IAS 36 - 'Impairment of Assets' - since 2005. Therefore, this paper examines empirically the effects of IAS 36 on asset impairment reporting, investigating whether IAS 36 reduces the magnitude and restricts the timing of reporting asset impairment. Additionally, we also analyse the influence of audit quality on the use of the asset impairment test as a tool to manage earnings. We use an OLS regression model to examine the effect of the asset impairment on earnings management for a sample of 33 nonfinancial-listed Portuguese companies from 2002 to 2010. We find that IAS 36 does not affect the magnitude of the reported asset impairment. Additionally, the results suggest that impairment firms are engaging in either 'big bath' or 'income smoothing' behaviour. Our findings also suggest that firms audited by Big 4 firms take significantly more impairments than firms audited by non-Big 4 firms. Furthermore, the results show that when there are incentives to underreport earnings, the likelihood of taking an asset impairment will increase more for firms audited by a non-Big 4 audit firm than for firms audited by a Big 4 audit firm. The findings based on this study provide useful information for the International Accounting Standards Board and other standard setters. The results also provide useful information to investors in evaluating the impact of IAS 36 on earnings quality.
\end{abstract}




\section{INTRODUCTION}

The writing down of accounting values that are not recoverable, whether due to obsolescence, physical damage or market conditions, is a long-lived convention in historical cost accounting. Since the adoption of the European Union (EU) Fourth Directive requirements into Portuguese company legislation, there has also been a legal obligation to account for impairment losses on non-financial fixed assets. Until recently, however, there was little guidance on how to detect impairments and carry out the appropriate accounting. Consequently, impairment accounting has been, to a certain degree, at the discretion of each reporting entity.

Since 1 January 2005 all listed EU companies must prepare their consolidated financial statements in accordance with International Financial Reporting Standards (IFRS) (Regulation, European Commission, 1606/2002). Therefore, Portuguese listed companies must also use the International Accounting Standards No. 36 (IAS 36) - 'Impairment of Assets' - to evaluate whether the assets have been impaired.

The objective of IAS 36 is the reflection of the true value of a firm's assets on its balance sheet. More specifically, IAS 36 is designed to ensure that assets are carried at no more than their recoverable amount and to define how the recoverable amount is calculated. Assets to which IAS 36 applies include long-term assets, longterm investments and intangible assets.

IAS 36 was intended to provide more structure on the determination and reporting of asset impairments. However, its effect on the characteristics of reported asset write-offs is unclear a priori, as implementation requires inherently subjective estimates. In particular, firms need to assess whether the carrying amount of assets (i.e. the value on the balance sheet) does not exceed the true or real value. If the carrying value of the asset exceeds the recoverable amount, impairment is necessary. Nevertheless, with the test of impairment, managers are able to exercise their discretion over the calculation of this recoverable amount (Caplan and Harris, 2002). Consequently, the standard provides managers with considerable discretion about how to assess the true value (recoverable amount) of the firm's assets. This means that the recognition of an impairment loss is based on the management's judgement about the necessity of the recognition of this loss. For example, firms can take an impairment loss when earnings are particularly high in order to smooth income, or, alternatively, they can 'take a bath' by recording an impairment loss when earnings are already poor (Alciatore, Dee, Easton and Spear, 1998, p. 1).

Empirical research also suggests that firms use their discretion over asset impairment to manage earnings (e.g. Francis, Hanna and Vincent, 1996; Rees, Gill and Gore, 1996; Sevin and Schroeder, 2005; Van de Poel, Maijoor and Vanstraelen, 2009; Zucca and Campbell, 1992). For example, using United States (US) data Francis et al. (1996) investigated a sample of firms making write-offs between 1989 and 1992, including some described as restructuring charges. They found factors associated with both earnings manipulation and asset impairment to be important determinants in write-off decisions.

Since the recoverable value is difficult to obtain objectively, management can discretionally assess the magnitude of the write-down to affect the reported profit (Andrews, 2006). By applying an impairment test in practice, a large amount of 
factors need to be determined for the impairment calculation, including the value in use, the carrying amount and fair value. These factors, used in an impairment test, depend on several assumptions made by management, since it is responsible for preparing the initial impairment calculation. The auditor is only obliged to check this calculation. A key element of the financial reporting process is to guarantee an independent verification of the financial statements prepared by the firm's management (Chan, Ezzamel and Gwilliam, 1993). It is widely known that external auditors play a central role in ensuring the integrity of the financial reporting process (e.g. Cohen, Krishnamoorthy and Wright, 2004; Johl, Jubb and Houghton, 2007; Vafeas, 2005). Previous research shows that higher audit quality is associated with higher earnings quality (e.g. Becker, DeFond, Jiambalso and Subramanyam, 1998; Francis, Maydew and Sparks, 1999; Balsam, Krishnan and Yang, 2003). However, Jonhson (2007) and Pannese and DelFavero (2010), for example, express concerns about auditors who may lack the necessary training in valuation methods for estimating fair values. They suggest that the most important opportunities to manage earnings are present in the area of cash flow projections.

Summing up, prior to the issuance of IAS 36, no explicit guidance existed on accounting for the impairment of long-lived assets. This absence of explicit guidance for asset impairments allowed substantial management discretion over amounts, presentation and timing of impairments. However, post-IAS 36, management presumably would have less discretion in reporting higher amounts of asset impairment losses and in the timing of when to report asset impairments since it provides some structure and rules that can be enforced by auditors. Therefore, it is expected that IAS 36 would reduce the magnitude and restrict the timing of reporting asset impairments.

From a different viewpoint, the issuance of IAS 36 may not eliminate or reduce management discretion in the timing and amount of asset impairments. In fact, the approach of the International Accounting Standards Board (IASB) in IAS 36 gives management substantial flexibility to exercise judgement in determining and reporting impairment losses. There are some areas of IAS 36 in which its application is subject to the judgement and assumptions of management, such as the definition of impairment indicators, the estimation of future cash flows from the use of the asset, the asset grouping level at which testing and measurement occurs, and the depreciation methods chosen for the asset. Therefore, this study investigates these two viewpoints and analyses the effect of IAS 36 on asset impairment reporting. It investigates whether IAS 36 reduces management's discretion over asset impairment magnitude and timing. Additionally, we also analyse the influence of audit quality on the use of the asset impairment test as a tool to manage earnings. Using a sample of thirty-three Euronext Lisbon non-financial firms over a period of nine years, from 2002 through 2010, we find that IAS 36 does not affect the magnitude of the reported asset impairment. We also find evidence that firms impair their assets more often when earnings are unexpectedly low or high. This suggests that impairment firms are engaging in either 'big bath' or 'income smoothing' behaviour. Our findings also suggests that companies audited by Big 4 firms take significantly more impairments than firms audited by non-Big 4 firms, suggesting that nonBig 4 auditors give firms more discretion to engage in income-increasing earnings 
management by postponing asset impairments. Additionally, the results show that when there are incentives to under-report earnings, the likelihood of taking an asset impairment will increase more for companies audited by a non-Big 4 audit firm than for firms audited by a Big 4 audit firm.

This study makes some interesting contributions to the existing literature. First, asset write-offs can be an important corporate event due to the amounts involved and their implication on firm performance and market value (Bartov, Lindahl and Ricks, 1998; Hirschey and Richardson, 2002). Second, the issue of whether IAS 36 constrains management's discretion in recognising asset impairment losses does not appear to have been investigated in the prior literature. Third, standard setters need to know which standards and which accruals are being used to manage earnings. Such information will highlight areas in need of corrective action by the standard setters. Therefore, information as to whether IAS 36 is being used to manage earnings, via asset impairment write-offs, would be useful for the IASB and other standard setters. In fact, if the asset impairment rule is being used as a tool for earnings management, both the asset value and the level of earnings reported in the financial statements may be distorted. The findings of this study should be of interest to regulators and investors, who are concerned about earnings management and improving the quality of financial reporting. Since 2005, listed groups in Ireland have been required to prepare their consolidated financial statements in accordance with IFRS. This study should be of interest for Ireland too. The importance of accounting practices for asset impairments is heightened during periods of ongoing economic uncertainty as a result of the need for companies to reflect the loss of economic value in a timely fashion through the mechanism of asset write-downs.

This paper is structured as follows. In the next section, we give a brief overview of IAS 36 - 'Impairment of Assets'. Following that, we provide an overview of the literature review and develop testable hypotheses. We then present the variable measurement and describe the research methodology. Next, the sample selection process and characteristics of the sample are presented. The results are reported and discussed, and we provide sensitivity tests in the following two sections. Finally, we conclude the study.

\section{BACKGROUND OF IAS 36 - 'IMPAIRMENT OF ASSETS'}

One of the important regulatory requirements of financial reporting is that the carrying amounts of assets, which are disclosed in financial statements, should not exceed their recoverable amounts.

Before IAS 36, Portuguese listed companies generally wrote down an asset when there was evidence of permanent impairment in the ability to fully recover the asset's carrying amount. However, accounting standards generally did not address when impairment losses should be recognised or how they should be measured, and thus different practices were followed. Managers had the opportunity to estimate how much and when to record asset impairment losses. This gave management some ability to manage their firm's earnings in their own or their firm's best interest. 
The IASB objective in issuing IAS 36 was to provide greater comparability and consistency in the accounting treatment of impairment of assets. In particular, this standard sought to address:

- The criteria for when to test for the existence of an impairment

- The level at which to group assets in impairment tests

- The measurement basis for determining the existence of an impairment

- The measurement of the impairment

- The presentation of the recognised amount

The objective of IAS 36 is to prescribe the procedures that an entity applies to ensure that its assets are carried at no more than their recoverable amount. An asset is carried at more than its recoverable amount if its carrying amount exceeds the amount to be recovered through use or sale of the asset. For these cases, the asset is described as impaired and the standard requires the entity to recognise an impairment loss.

An entity shall verify at each reporting date whether there is some indication that an asset may be impaired; if it exists, the entity shall estimate the recoverable amount of the asset. Therefore, the accounting principle is to test each asset for impairment loss, in order to determine if there are indications in both the internal and external environments that the asset might have been impaired. However, irrespective of whether there is any indication of impairment, goodwill and intangible assets that have indefinite useful lives should be tested at least annually for impairment.

If there is any indication that an asset may be impaired, the recoverable amount shall be estimated for the individual asset. If it is not possible to estimate the recoverable amount of the individual asset, an entity shall determine the recoverable amount of the cash-generating unit to which the asset belongs. Determination of the cash-generating unit is left to the management's judgement.

The recoverable amount of an asset or a cash-generating unit is obtained by choosing the higher value of two options: the fair value less costs to sell, and the value in use. The value in use is defined as 'the present value of estimated future cash flows expected to arise from the continuing use of an asset and from its disposal at the end of its useful life' (International Accounting Standards Board, 1998, s. 6).

According to IAS 36, the following elements shall be reflected in the calculation of an asset's value in use:

- An estimate of the future cash flows the entity expects to derive from the asset

- Expectations about possible variations in the amount or timing of those future cash flows

- The time value of money, represented by the current market risk-free rate of interest

- The price for bearing the uncertainty inherent in the asset 
- Other factors such as illiquidity that market participants would reflect in pricing the future cash flows the entity expects to derive from the asset

If, and only if, the recoverable amount of an asset is less than its carrying amount, the carrying amount must assume the value of the recoverable amount. That reduction is an impairment loss. An impairment loss must be recognised immediately in the profit and loss account, unless the asset is carried at a revalued amount in accordance with another standard (for example, in accordance with the revaluation model in IAS 16 - 'Property, Plant and Equipment').

Although the intention of the impairment accounting regulations by IAS 36 is to avoid the overstatement of assets on the one hand, and to allow companies to reflect impairment recovery on the other hand, concerns have been expressed in the literature that companies may manage earnings opportunistically through impairments (Francis et al., 1996; Rees et al., 1996; Sevin and Schroeder, 2005; Van de Poel et al., 2009; Zucca and Campbell, 1992).

In fact, the above discussion reveals that substantial assumptions and estimates are generally required to implement IAS 36 . Thus, the standard's effect on managerial discretion exercised to arrive at reported write-offs is unclear. Similarly, the standard's criteria for determining an impairment (e.g. the use of expected future cash flows) may or may not enhance the mapping of economic declines into the reported decreases in asset values.

Summing up, IAS 36 seems to give substantial latitude for management to select the timing and amount of asset impairment. As referred to previously, the impairment loss is measured as the difference between an asset's book value and its recoverable amount. However, in most cases, the recoverable amount must be estimated, and the estimation process usually involves a forecast of future net cash flows the company expects to generate from the asset's use. So, for example, if a company underestimates future net cash flows, the recoverable amount is understated. This has two effects: (1) the current year's income is unrealistically low due to the impairment loss being overstated and (2) future income is unrealistically high because depreciation, depletion and amortisation are based on understated asset values. As a result, reducing management discretion over the timing and amount of asset impairment by the issuance of IAS 36 is somewhat questionable.

\section{LITERATURE REVIEW AND TESTABLE HYPOTHESES}

Earnings management is the intentional intervention in the external financial reporting process with the intent of obtaining some private gains (Schipper, 1989). It 'occurs when managers use judgment in financial reporting and in structuring transactions to alter financial reports to either mislead some stakeholders about the underlying economic performance of the company or to influence contractual outcomes that depend on reported accounting numbers' (Healy and Wahlen, 1999, p. 365).

There are a number of reasons why management might adjust earnings in such a way that the adjustment might have either a positive or negative effect on the users' 
ability to predict a firm's performance (e.g. management compensation contracts, debt contracts, stock market, and political and regulatory requirements). One technique that explains management incentive in managing earnings through the use of asset impairments is the 'big bath' hypothesis. Strong and Meyer (1987) argue that through cleaning up the balance sheet and reducing equity, a company can boost future profits and increase per-share return. So, management might choose to take all negative adjustments to income in one year in an effort to 'clear' the accounting records (Cameron and Stephens, 1991). By taking significant write-downs all in one year, management could be signaling that better times are ahead. In the case of asset impairments, this reasoning is particularly appropriate, since an asset impairment results in decreased depreciation expense in the future.

Income smoothing is another technique that explains management incentive in managing earnings through the use of asset impairments. It describes an earnings pattern in which management aspires to maintain a steady and predictable rate of earnings growth. Consequently, a firm with an impaired asset might choose to adjust earnings downward in a year when earnings from ongoing operations are unusually high but are not expected to be as high in future years, or it might time the loss recognition to coincide with a non-discretionary gain.

Therefore, firms could record an impairment when earnings are particularly high to smooth income, or, alternatively, they could 'take a bath' by accelerating an impairment when earnings are already poor to maximise profits in future periods. This flexibility suggests that impairment decisions could be strategically used by managers to adjust the timing and amounts of charges to income (Alciatore et al., 1998).

\section{IAS 36 and Earnings Management}

Empirical studies suggest that the demands for authoritative guidance on accounting for asset impairments appear to be based on a notion that management takes advantage of the discretion afforded by the accounting rules to manipulate earnings (Francis et al., 1996; Van de Poel et al., 2009). Earnings could be manipulated either by not recognising impairment when it has occurred or by recognising it only when it is advantageous to do so. Moreover, since managers have incentives to manage earnings and investors are unable to undo these manipulations, an authoritative guidance on asset impairment was needed. Therefore, IAS 36 was issued in order to restrict management's opportunities of managing earnings through asset impairment decisions. As a result, we expect that the issuance of IAS 36 restricts management's discretion over the magnitude of the reported asset impairment loss.

Prior to the issuance of IAS 36, no explicit guidance existed on accounting for the impairment of long-lived assets. This absence of explicit guidance for asset impairments permitted substantial management discretion over amounts, presentation and timing of impairments. However, post-IAS 36, management presumably would have less discretion in reporting higher amounts of asset impairment losses and in the timing of when to report asset impairments since the standard provides some structure and rules that can be enforced by auditors. So, this study posits that the issuance of IAS 36 restricts management's discretion over the magnitude of the reported asset impairment loss and the discretion over when to report such events. 
Therefore, it is expected that IAS 36 would reduce the magnitude and restricts the timing of reporting asset impairments. Therefore, we hypothesize that:

$\mathbf{H}_{\mathbf{1}}$ : IAS 36 reduces the magnitude of impairment losses relative to pre-IAS 36.

However, IAS 36 leads to the need for more professional judgement, therefore bringing a higher degree of subjectivity in the valuation of non-financial fixed assets in the financial statements. This subjectivity provides opportunities for management to manipulate earnings. Asset impairment losses affect the magnitude of the accruals, because they lower the reported earnings while they have no influence on the cash flows from operations. Therefore, accounting for impairment loss provides significant scope for earnings management (Alciatore et al., 1998; Ball, 2006; Bini and Bella, 2007), and, according to Zucca and Campbell (1992), earnings management can be seen as a possible explanation for the timing and amount of discretionary impairments. Two techniques that explain management incentive in managing earnings through the use of asset impairment are the big bath and income smoothing. The unexpected earnings direction specifies which technique will be used when managing earnings. The big bath technique is adopted in periods of unexpected negative earnings, whereas the income smoothing technique is adopted in periods of unexpected positive earnings (Zucca and Campbell, 1992).

\section{Asset Impairment and 'Big Bath'}

The 'big bath' hypothesis suggests that if earnings are extremely low, managers are likely to take income-decreasing accruals to further reduce current earnings so that (1) the probability of appearing better in the future will increase, and (2) a lower benchmark for subsequent evaluation will be established (Murphy and Zimmerman, 1993; Pourciau, 1993; Guidry, Leone and Rock, 1999).

Therefore, for firms with unexpected negative earnings (big bath firms), reporting additional asset impairment losses would lead to a better accounting performance in future periods. By reporting asset impairment losses in the current year, future depreciation expenses would be reduced, which would increase the reported net income in future years. Also, the return-on-asset ratio would increase in the future since the non-financial fixed asset amounts would decrease and earnings would increase. Therefore, by using fewer resources to achieve higher earnings, these companies may be perceived by the market as better performers.

Some studies corroborate the big bath hypothesis. For example, using US data, Zucca and Campbell (1992) found that the majority of the firms surveyed wrote down their assets in a period of already below normal earnings (the big bath hypothesis). Chen and Lee (1995), studying US oil and gas companies in the mid-1980s, found that the likelihood of a write-down was larger for firms with accounting losses before the write-down. Rees et al. (1996) found that management acts opportunistically in the year of the write-down to improve reported earnings of future years for a sample of US firms. Riedl (2004) also provided evidence of the relationship between big bath reporting behaviour and the reporting of asset impairment losses. Also using US data, Jordan and Clark (2004) found evidence that companies with unusually low earnings in a year similarly reported a large impairment loss, which 
is suggestive of big bath accounting. Spear and Taylor (2011) concluded as well that under-performing US firms tend to take larger write-downs than other firms, which may indicate opportunistic big bath accounting by these firms. Yoon and Miller (2002), using a sample of South Korean firms, found that when the operating performance is extremely poor, some firms tend to take a big bath. For a sample of Taiwanese listed firms, Chao (2006) concluded that firms with extremely low earnings tend to take a big bath by reporting a larger magnitude of asset write-offs. Dai, Mao and Deng (2007) examined whether Chinese-listed firms with negative earnings manipulate earnings by the impairment of assets and they found evidence that listed firms with negative earnings have taken a big bath. Finally, in Europe, Van de Poel et al. (2009) studied whether the IFRS goodwill impairment test is used by European firms as a tool to manage earnings. Using a sample of listed companies in fifteen EU countries with financial statements prepared under IFRS for the period 2005-2006, their results support the fact that companies typically take their impairments when earnings are unexpectedly low (big bath accounting).

Therefore, managers may have incentives to take a 'big bath' in periods in which pre-write-down earnings are below expectations to improve future reported performance. An asset impairment test may provide managers with the necessary discretion to engage in this form of earnings management. Therefore, we hypothesize that:

$\mathbf{H}_{2}$ : Firms are more likely to recognise an impairment loss when their earnings are unexpectedly low, ceteris paribus.

\section{Asset Impairment and 'Income Smoothing'}

Income smoothing is another technique that explains management incentives in managing earnings through the use of asset impairment. According to the income smoothing hypothesis, management seeks to reduce the variability in the trend of reported income with accounting decisions (Eckel, 1981). Various reasons have been suggested as to why managers might attempt to smooth earnings. They may believe that smooth earnings are more highly valued or that smooth earnings minimise the risk of possible debt and dividend covenant violations. That is, smooth income creates an impression of reduced risk in the eyes of the participants in the financial markets. Therefore, the income smoothing hypothesis predicts that managers will tend to use income-decreasing accruals in a year when earnings are unusually high. Thus, a firm with an impaired asset might choose to adjust earnings downward in a year when earnings are unusually high but are not expected to be as high in future years, or it may time the loss recognition to coincide with a non-discretionary gain. In this manner, management could smooth income and increase predictability of a firm's performance.

Prior literature shows that asset impairment losses have been used to smooth earnings (e.g. McNichols, Wilson and DeAngelo, 1988; Kinney and Trezevant, 1995; Zucca and Campbell, 1992). Using US data, McNichols et al. (1988) found that firms have more impairment of assets when their earning level is higher or lower than others, which suggests that firms have an incentive to smooth earnings. Zucca and Campbell (1992) found that 25 per cent of the US firms surveyed 
offset the write-down with other gains or unusually high earnings (the income smoothing hypothesis). Jahmani, Dowling and Torres (2010), using US data, tested whether management deliberately selects the timing of goodwill impairment recognition as a means to smooth the company's earnings. Their results suggest that most companies are attempting to manage the volatility of earnings by avoiding taking impairment losses in the period studied to avoid exacerbating the losses. Van de Poel et al. (2009) studied whether the IFRS goodwill impairment test is used as a tool to manage earnings. Using a sample of listed companies in fifteen EU countries with financial statements prepared under IFRS in the period 2005-2006, they obtained results supporting the fact that companies typically take their impairments when earnings are unexpectedly high (smoothing).

Managers have incentives to smooth earnings in case of high unexpected earnings and to under-report earnings by the maximum. An asset impairment test may provide managers with the necessary discretion to engage in this form of earnings management. Therefore, we hypothesize that:

$\mathbf{H}_{3}$ : Firms are more likely to recognise an impairment loss when their earnings are unexpectedly high, ceteris paribus.

\section{Asset Impairment and Audit Quality}

Auditing is considered an important monitoring mechanism (Jensen and Meckling, 1976; Watts and Zimmerman, 1983). Therefore, the auditing process is supposed to serve as a monitoring device that reduces management incentives to manipulate reported earnings. Although auditing is an important way to limit earnings management, its effectiveness is likely to vary with the quality of the auditor (Becker et al., 1998).

Audit quality research has focused primarily on differences between big firm auditors and non-big firm auditors. Several studies suggest that higher quality (big firm) auditors reduce the level of accrual earnings management (e.g. Becker et al., 1998; Caneghem, 2004; Gul, Lynn and Tsui, 2002; Gul, Tsui and Dhaliwal, 2006; Jordan, Clark and Hames, 2010; Krishnan, 2003; Lin and Hwang, 2010) and big audit firms used more conservative accounting methods (Chung, Firth and Kim, 2003; Basu, Hwang and Jan, 2002).

Therefore, high-quality audit firms are more likely to detect any overly optimistic assumptions in the impairment test and accordingly force firms to adjust these conjectures downwards. Similar to preventing income-increasing earnings management, high-quality auditors are expected to be more likely to constrain income-decreasing behaviour in cases of unexpectedly high earnings (Van de Poel et al., 2009). As a result, we hypothesize that:

$\mathbf{H}_{4 \mathrm{a}}$ : Big 4 audit firms restrain the use of discretionary asset impairment losses to take a 'big bath'.

$\mathbf{H}_{4 \mathrm{~b}}$ : Big 4 audit firms restrain the use of discretionary asset impairment losses to smooth earnings. 
However, other studies suggest that auditors are less likely to adjust earnings management attempts when accounting standards are imprecise or require judgements (Healy and Wahlen, 1999; Nelson, Elliott and Tarpley, 2002; Nelson, 2003). Watts (2003) argues that assessing fair values requires managers to estimate future cash inflows and outflows and those estimates are unlikely to be verifiable and contractible, thus, valuations based on them are likely to be manipulated. As a result, auditors may not contribute to reducing earnings management.

\section{VARIABLE MEASUREMENT AND RESEARCH DESIGN}

\section{Measuring Dependent and Independent Variables}

- Asset impairment (Impairment), the dependent variable, is measured as the reported asset impairment amount for firm $i$ in year $t$, deflated by the total asset.

- IAS 36 - we use a dichotomous variable that equals 1 if the firm is subject to the rules of IAS 36, and 0 if not.

- Big bath (Bath) - following Bartov (1993), Francis et al. (1996) and Riedl (2004) as a proxy for big bath behaviour, we use an indicator variable that equals 1 if the change in a firm's pre-write-down earnings divided by lagged total assets is below the median of non-zero negative values, and 0 otherwise. In this case earnings are unexpectedly low.

- Income smoothing (Smooth) is also used an indicator variable to proxy income smoothing. This variable is equal to 1 if the change in a firm's pre-write-down earnings divided by lagged total assets is above the median of non-zero positive values for this variable and 0 otherwise.

- Audit quality (Big4) - consistent with prior research (e.g. Becker et al., 1998; Chen, Lin and Zhou, 2005; Chi, Lisic and Pevzner, 2011; Li and Lin, 2005; Lin, Li and Yang, 2006; Rahman and Ali, 2006; Sun, Liu and Lan, 2011), we measure external audit as a dichotomous variable equal to 1 if the auditor is a Big 4 audit firm (Deloitte Touche Tohmatsu, Ernst \& Young, KPMG or PricewaterhouseCoopers), and 0 otherwise.

\section{Regression Models and Control Variables}

The first hypothesis states that IAS 36 reduces the magnitude of asset impairment relative to the magnitude of asset impairment pre-IAS 36 . We estimate the following ordinary least squares (OLS) regression:

$$
\text { Impairment }_{i t}=\beta_{0}+\beta_{1}\left(\text { IAS } 36_{i t}\right)+\varepsilon_{i t}
$$

Where:

- Impairment $_{i t}=$ reported asset impairment amount for firm $i$ in period $t$ deflated by the total assets of the same year $t$ 
- IAS $36_{i t}=1$ if the observation for firm $i$ collected in year $t$ is subject to the rules of IAS 36, and 0 if not

- $\varepsilon_{i t}=$ residual term of firm $i$ for period $t$

- $\beta_{0}$ is a constant, $\beta_{1}$ is the coefficient

Hypothesis $\mathrm{H}_{2}$ states that IAS 36 restricts the timing of reporting asset impairment such that the number of firms with negative (positive) unexpected earnings that have reported asset impairment will be fewer post-IAS 36 than the number of firms with negative (positive) unexpected earnings that have reported asset impairment pre-IAS 36. The following OLS regression is used to test hypothesis $\mathrm{H}_{2}$ :

$$
\text { Impairment }_{i t}=\beta_{0}+\beta_{1}\left(\text { IAS 36 }_{i t}\right)+\beta_{2}\left(\text { Bath }_{i t}\right)+\beta_{3}\left(\text { Smooth }_{i t}\right)+\varepsilon_{i t}
$$

Where:

- Impairment $t_{i t^{\prime}}$ IAS $36_{i t}$ and $\varepsilon_{i t}=$ as defined previously

- $B a t h_{i t}=$ dummy variable: 1 if the change in firm $i$ 's pre-impaired earnings from year $t-1$ to $t$, divided by total assets at year $t-1$, is below the median of non-zero negative values, and 0 otherwise

- Smooth $_{i t}=$ dummy variable: 1 if the change in firm $i$ 's pre-impaired earnings from year $t-1$ to $t$, divided by total assets at year $t-1$, is above the median of nonzero positive values, and 0 otherwise

- $\beta_{0}$ is a constant, $\beta_{1}$ to $\beta_{3}$ are the coefficients

Additionally, we also analyse the influence of audit quality on the use of the asset impairment test as a tool to manage earnings, by estimating the following OLS regression:

$$
\text { Impairment }_{i t}=\beta_{0}+\beta_{1}\left(\text { IAS 36 }_{i t}\right)+\beta_{2}\left(\text { Bath }_{i t}\right)+\beta_{3}\left(\text { Smooth }_{i t}\right)+\beta_{4}\left(\text { Bigt }_{i t}\right)+\varepsilon_{i t}
$$

Where:

- Impairment ${ }_{i t^{\prime}}$ IAS $36_{i t^{\prime}}$ Bath $_{i t^{\prime}}$ Smooth $_{i t}$ and $\varepsilon_{i t}=$ as defined previously

- Big $_{i t}=$ dummy variable: 1 if the auditor is a Big 4 firm and 0 otherwise

To examine the potential interaction effect between audit quality and incomedecreasing incentives, we include interaction terms between the Bath and Smooth variables and the Big4 variable, by estimating the following OLS regression:

$$
\begin{aligned}
\text { Impairment }_{i t} & =\beta_{0}+\beta_{1}\left(\text { IAS 36 }_{i t}\right)+\beta_{2}\left(\text { Bath }_{i t}\right)+\beta_{3}\left(\text { Smooth }_{i t}\right)+\beta_{4}\left(\text { Big4 }_{i t}\right) \\
& +\beta_{5}\left(\text { Bath }_{i t}^{*} \text { Big }_{i t}\right)+\beta_{6}\left(\text { Smooth }_{i t}{ }^{*} \text { Big }_{i t}\right)+\varepsilon_{i t}
\end{aligned}
$$


Given that earnings management, audit quality (Big 4/non-Big 4) and the interaction of these variables are not the only factors affecting the asset impairment decision, we also evaluate the association between these variables and asset impairment, after controlling the impact of other relevant variables. Several control variables are introduced to isolate other contracting incentives that may influence management's accounting choices. Previous studies suggest that firm leverage $(L e v)$, growth options (Growth) and size (Size) are associated with the asset impairment decision (Beatty and Weber, 2006; Francis et al., 1996; Lemans, 2009; Zang, 2008; Zucca and Campbell, 1992). Additionally, we also control the crisis period by including the crisis variable (Crisis).

The association between earnings management, audit quality and interaction between these two variables and asset impairment, controlling the impact of other relevant variables, is estimated using the following OLS regressions:

$$
\begin{aligned}
& \text { Impairment }_{i t}=\beta_{0}+\beta_{1}\left(\operatorname{IAS~36} 6_{i t}\right)+\beta_{2}\left(\text { Lev }_{i t}\right)+\beta_{3}\left(\text { Growth }_{i t}\right)+\beta_{4}\left(\text { Size }_{i t}\right) \\
& +\beta_{5}\left(\text { Crisis }_{i t}\right)+\varepsilon_{i t} \\
& \text { Impairment }_{i t}=\beta_{0}+\beta_{1}\left(\text { IAS 36 }_{i t}\right)+\beta_{2}\left(\text { Bath }_{i t}\right)+\beta_{3}\left(\text { Smooth }_{i t}\right)+\beta_{4}\left(\text { Lev }_{i t}\right) \\
& +\beta_{5}\left(\text { Growth }_{i t}\right)+\beta_{6}\left(\text { Size }_{i t}\right)+\beta_{7}\left(\text { Crisis }_{i t}\right)+\varepsilon_{i t} \\
& \text { Impairment }_{i t}=\beta_{0}+\beta_{1}\left(\text { IAS 36 }_{i t}\right)+\beta_{2}\left(\text { Bath }_{i t}\right)+\beta_{3}\left(\text { Smooth }_{i t}\right)+\beta_{4}\left(\text { Big4 }_{i t}\right) \\
& +\beta_{5}\left(\text { Lev }_{i t}\right)+\beta_{6}\left(\text { Growth }_{i t}\right)+\beta_{7}\left(\text { Size }_{i t}\right)+\beta_{8}\left(\text { Crisis }_{i t}\right)+\varepsilon_{i t} \\
& \text { Impairment }_{i t}=\beta_{0}+\beta_{1}\left(\text { IAS 36 }_{i t}\right)+\beta_{2}\left(\text { Bath }_{i t}\right)+\beta_{3}\left(\text { Smooth }_{i t}\right)+\beta_{4}\left(\text { Big4 }_{i t}\right) \\
& +\beta_{5}\left(\text { Bath }_{i t}{ }^{*} \text { Big4 }_{i t}\right)+\beta_{6}\left(\text { Smooth }_{i t}{ }^{*} \text { Big }_{i t}\right)+\beta_{7}\left(\text { Lev }_{i t}\right) \\
& +\beta_{8}\left(\text { Growth }_{i t}\right)+\beta_{9}\left(\text { Size }_{i t}\right)+\beta_{10}\left(\text { Crisis }_{i t}\right)+\varepsilon_{i t}
\end{aligned}
$$

Where:

- Impairment ${ }_{i t^{\prime}}$ IAS 36 ${ }_{i t^{\prime}}$ Bath $_{i t^{\prime}}$ Smooth $_{i t^{\prime}}$ Big $_{i t^{\prime}}$ Bath $_{i t}{ }^{*}$ Big $_{i t^{\prime}}$ Smooth $_{i t}{ }^{*}$ Big4 $4_{i t}$ and $\varepsilon_{i t}=$ as defined previously

- $L e v_{i t}=$ the ratio between the book value of all liabilities and the total assets of firm $i$ for period $t$

- Growth $_{i t}=$ book value of equity divided by market value of equity at the end of $t$

- Size $_{i t}=$ logarithm of market value of equity of firm $i$ for period $t$

- Crisis $_{i t}=$ is a dummy variable which is equal to 1 during the crisis period (Financial crisis: 2007-2008; European sovereign debt crisis: 2010)

- $\quad \beta_{0}$ is a constant, $\beta_{1}$ to $\beta_{10}$ are the coefficients

\section{Control Variables Explained}

Watts and Zimmerman (1986, 1990) argue that accounting choices are affected by a firm's debt contracts. Previous studies suggest that the larger a firm's debt ratio, the more likely its managers are to engage in manipulation (e.g. DeFond and 
Jiambalvo, 1994; Jiang, Lee and Anandarajan, 2008; Sweeney, 1994). A large impairment loss charge will have a negative impact on the financial structure and debt covenant of a firm, because it reduces the amount of assets and, at the same time, it flows through the income statement into retained earnings, thus lowering stockholder equity. Consequently, highly leveraged firms may try to avoid violations of debt covenants by reducing the effect from asset impairment losses (Beatty and Weber, 2006; Zang, 2008).

Following IAS 36 guidelines, firms with an excess amount of book value over market value are more likely to incur asset impairment charges. In addition, Beatty and Weber (2006) argue that firms with more growth options are less likely to have impaired assets; therefore, they are less likely to take annual asset impairment losses. The impairment test under IAS 36 requires managers to consider not only backward-looking but also forward-looking information when they evaluate assets for impairment. Beatty and Weber (2006) find that firms with more growth options are less likely to take a write-off.

Francis et al. (1996) and Lemans (2009) find that larger firms are more likely to write down asset value. Nevertheless, larger firms are subject to closer scrutiny by the investment banks and analyst community, which may lead to more efficient processing of accounting information, and fewer managerial incentives to manipulate the impairment charge (Chao, 2006).

At times of economic uncertainty and persistent slowdown in financial markets and in the real economy, it is likely that assets may generate lower cash flows than previously expected. This could, in turn, increase the likelihood of booking impairment charges as carrying amounts may not be fully recoverable. As such, the crisis may act as the triggering event for impairment testing and the recognition of writedowns. Therefore, it would be expected that the volume of impairments would have increased during the crisis period.

\section{SAMPLE SELECTION AND CHARACTERISTICS}

The initial sample includes all companies whose stocks are listed in the main market, Euronext Lisbon. A total of 52, 50, 48, 51, 51, 51, 50, 49 and 52 companies were listed at the year end of 2002, 2003, 2004, 2005, 2006, 2007, 2008, 2009 and 2010 respectively (454 firm-year observations in total).

Foreign companies (30 in total) are excluded. Companies not having shares listed in the previous year and companies whose shares were delisted in the following year are also excluded (76 in total). Companies with missing data (six in total) are also excluded. Financial companies (45 in total) are excluded, too. As a result, the final sample size is 33 non-financial companies per year and, thus, 297 observations in total. This reduced number of observations may influence some results. Nevertheless, this limitation is an immediate consequence of the small size of the Portuguese stock market.

Information on asset impairment magnitude, audit quality (Big 4 audit firm or non-Big 4 audit firm), net income, total assets, total liabilities and total shareholders' 
equity (book value of equity) are collected from the annual reports and corporate governance reports of each firm. Both annual reports and corporate governance reports are available online at www.cmvm.pt. We obtain stock price data from Euronext Lisbon, which enable the measurement of the variables growth and firm size.

\section{RESULTS AND DISCUSSION}

\section{Descriptive Statistics}

Table 1 presents the sample descriptive statistics for the variables used in this research. The Impairment variable represents on average 1.3 per cent of the total assets of the company (with a median of 0.000). About 24 per cent of the firms adopt the big bath technique (Bath). The analysis of Table 1 also shows that about 19.4 per cent of companies adopt the income smoothing technique (Smooth). Big4 auditors are used by 70.3 per cent of the sample firms. The Lev variable represents on average 4.362 of the total assets of the company (with a median of 1.965). The descriptive statistics of the Growth show that, on average, firms in our sample exhibit a relatively low investment opportunities level with a mean of 0.351 (with a median of 0.637). The mean of firm size (Size) is about $€ 1.146$ million with a minimum of $€ 1,740$ and a maximum of $€ 16.347$ million.

\section{TABLE I: SUMMARY OF DESCRIPTIVE STATISTICS (NUMBER OF OBSERVATIONS: 297; PERIOD: 2002-2010)}

\begin{tabular}{lcccc}
\hline \multicolumn{1}{c}{ Variable } & Mean & Median & Minimum & Maximum \\
\hline Impairment & 0.013 & 0.000 & 0.006 & 0.236 \\
Bath & 0.240 & 0.000 & 0.000 & 1.000 \\
Smooth & 0.194 & 0.000 & 0.000 & 1.000 \\
Big4 & 0.703 & 1.000 & 0.000 & 1.000 \\
Lev & 4.362 & 1.965 & 0.284 & 8.259 \\
Growth & 0.351 & 0.637 & -56.742 & 10.525 \\
Size & 20.195 & 20.205 & 16.971 & 24.450 \\
\hline
\end{tabular}

Impairment is the asset impairment magnitude for firm $i$ in period $t$ deflated by the total assets of the same year $t$; Bath is a dummy variable which takes a value of $I$ if the change in firm i's pre-impaired earnings from year $t-I$ to $t$, divided by total assets at year $t-I$, is below the median of non-zero negative values, and 0 otherwise; the Smooth dummy variable takes a value of $I$ if the change in firm i's pre-impaired earnings from year $t$ - $I$ to $t$, divided by total assets at year $t-l$, is above the median of non-zero positive values, and 0 otherwise; Big4 dummy variable takes a value of $\mathrm{I}$ if the auditor is a Big 4 firm; Lev represents the ratio between the book value of all liabilities and the total assets; Growth is the book-to-market ratio; Size represents the firm's size.

Spearman correlations between the explanatory variables are documented in Table 2. The binary variables (IAS 36, Bath, Smooth, Big4 and Crisis) are not included in the table, given that the Pearson correlation coefficient is not computed to nominal variables. 
TABLE 2: PEARSON CORRELATION COEFFICIENTS MATRIX

\begin{tabular}{lcclc}
\hline & Impairment & Lev & Growth & Size \\
\hline Impairment & $\mathrm{I}$ & & & \\
Lev & $-0.270^{* * *}$ & $\mathrm{I}$ & & \\
Growth & 0.025 & $-0.512^{* * *}$ & $\mathrm{I}$ & \\
Size & $0.219^{* * *}$ & $-0.177^{* * * *}$ & $0.191^{* * *}$ & $\mathrm{I}$ \\
\hline
\end{tabular}

Impairment is the asset impairment magnitude for firm $i$ in period $t$ deflated by the total assets of the same year $t$; Lev represents the ratio between the book value of all liabilities and the total assets; Growth is the book-to-market ratio; Size represents the firm's size.

*** Correlation is significant at the 0.0 I level (2-tailed)

The analysis of Table 2 shows that there are some significant correlations between the variables. The asset Impairment is negatively associated with leverage (Lev), suggesting that highly leveraged firms tend to have lower amount of impairment loss. Size is positively correlated with Impairment, suggesting that large firms have high asset impairment magnitude, consistent with Francis et al.'s (1996) findings. A negative correlation between Lev and Growth indicates that firms with high leverage tend to have smaller investment opportunities. Size is negatively associated with Lev, suggesting that larger firms have lower leverage constraint levels. Growth is positively correlated with Size, suggesting that larger firms have higher investment opportunities. Correlation coefficients are, in general, low (below the 0.9 threshold) (Tabachnick and Fidell, 2001), suggesting the absence of serious statistical problems related with multicollinearity.

\section{Regression Results}

Table 3 presents OLS regression estimates for the equations developed in the section on variable measurement and research design.

The primary question of interest is whether or not the issuance of IAS 36 reduces the magnitude of asset losses relative to that before the application of IAS 36. A statistically significant and negative value for $\beta_{1}$ in these equations would suggest that IAS 36 decreased the reported asset impairment magnitude. However, the results indicate that IAS 36 did not have a significant effect on the reported asset impairment magnitude. This result is not surprising, since the IASB's approach in IAS 36 gives management substantial discretion about how to assess the true value (recoverable amount) of the firm's assets.

We find a positive relationship between both Bath and Smooth variables and asset impairment losses, suggesting that firms impair their assets more often when earnings are unexpectedly low (big bath) or high (smooth). These results are similar to Zucca and Campbell's (1992) conclusion that write-off firms are engaging in either big bath or smoothing behaviour.

We also find that the relationship between Big 4 and asset impairment is significantly positive. This means that firms audited by Big 4 firms take significantly more impairments than firms audited by non-Big 4 firms. Therefore, this finding is not consistent with the notion that Big 4 audit firms mitigate earnings management more than non-Big 4 audit firms. However, this result is consistent with some 
Asset Impairment and Earnings Management: Influence of Audit Quality

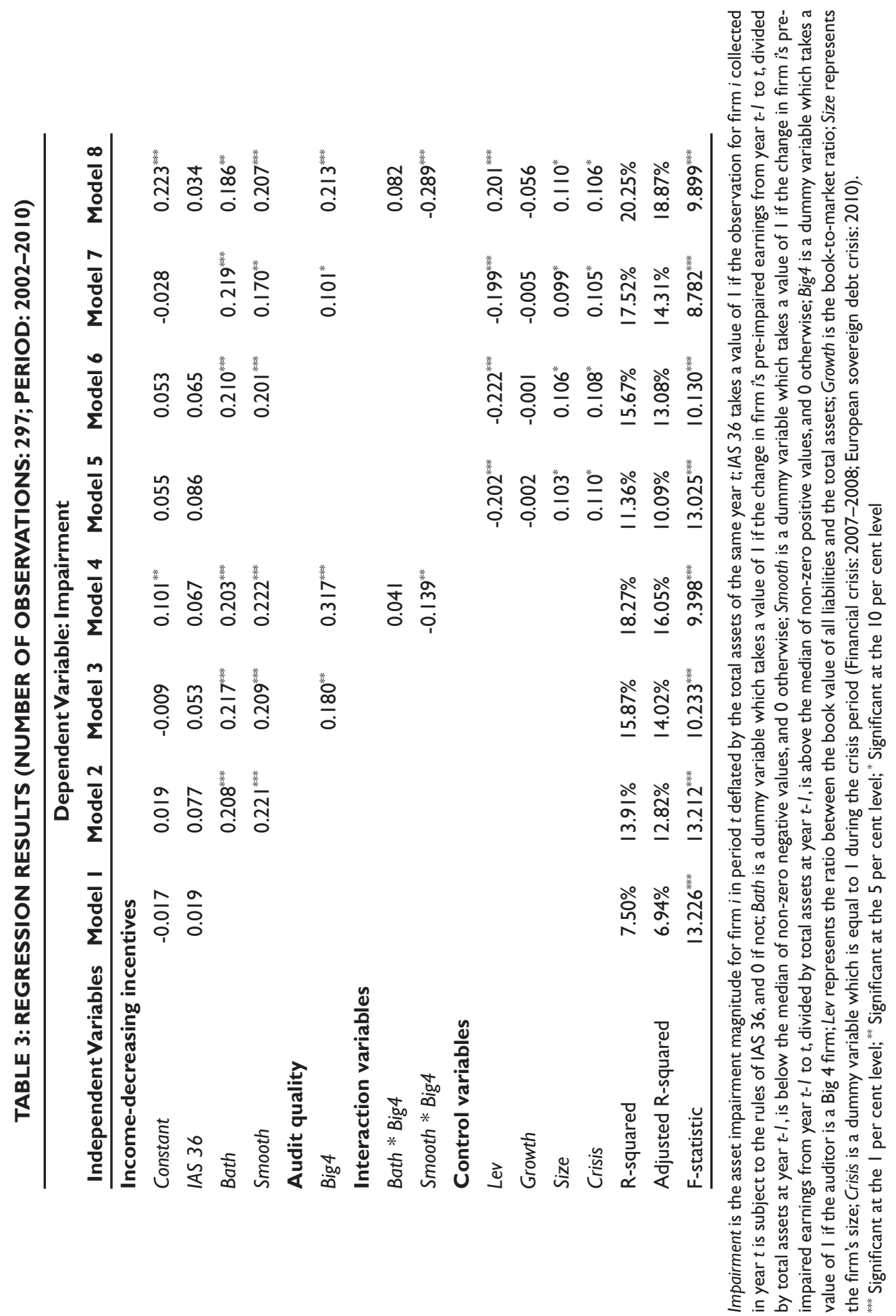


studies that show that auditors are less likely to require adjustments when the amounts involved are subjective (e.g. Braun, 2001; Nelson, Smith and Palmrose, 2005). In the same sense, other authors (Healy and Wahlen, 1999; Nelson et al., 2002; Nelson, 2003; Nelson, Elliott and Tarpley, 2003) suggest that auditors are less likely to adjust earnings management attempts when accounting standards are imprecise or require judgements. Since IAS 36 involves estimation of parameters such as cash flow and discount rate by the managers, the subjective component in the determination of the amount of impairment loss may give rise to earnings management opportunities. This result seems also to be consistent with the long list of corporate failures, which indicates that management have often engaged in earnings management, and Big 4 audit firms have not been effective in identifying and preventing unscrupulous accounting practices.

Additionally, the results show that the coefficients on the interaction term between the Big4 indicator and the Smooth variable have a negative sign. This finding suggests that when there are incentives to under-report earnings, the likelihood of taking an asset impairment will increase more for firms audited by a non-Big 4 audit firm than for firms audited by a Big 4 audit firm.

We find a negative relationship between Lev and asset impairment losses, suggesting that highly leveraged firms may try to avoid violations of debt covenants by reducing the amount of impairment loss. Therefore, existing debt covenants may introduce higher scrutiny on financial reporting processes including the exercise of accounting discretion with respect to IAS 36 impairment testing.

As in Beatty and Weber (2006), Francis et al. (1996), Haron and Atan (2010), Lemans (2009) and Zang (2008), we find that large firms (Size) have a higher amount of impairment loss. This means that larger firms are expected to recognise more and bigger asset impairment losses than smaller firms.

We find a positive relationship between Crisis and asset impairment losses, suggesting that firms recognise a higher amount of impairment loss during the crisis period.

Results suggest that Growth does not affect the amount of impairment loss.

\section{Sensitivity Analyses}

To ensure the robustness of our results, we perform several sensitivity checks. The first sensitivity analysis tests the impact of using alternative measures for the asset impairment (Impairment) variable on regression results. As in several studies (e.g. Beatty and Weber, 2006; Lemans, 2009; Van de Poel et al., 2009), the Impairment variable is determined using a dichotomous variable equal to 1 when the firm records an asset impairment loss and 0 otherwise. The results (not reported here) of the regressions, using alternative measures to measure Impairment (asset impairment) earnings management, have implications on the Bath and Lev variables, which lost significance level (from $p<0.01$ to $p<0.10$ ) in Models (2), (6) and (8). The other results remain unchanged (at coefficient signal and significance level).

The next sensitivity analysis examines the effect of influential observations on the results. Where outliers are found (namely in the variables Impairment, Lev and Size), a winsorisation method ${ }^{1}$ is used to test the robustness of the results. Extreme values (defined as values that are more than three standard deviations away from 
the mean) are replaced by values that are exactly three standard deviations away from the mean. The results (not reported here) do not differ from results presented previously in Table 3. Thus, the influential observations do not affect the results.

We also test the impact of using alternative definitions for the Size and the Growth variables on the results of Models (5), (6), (7) and (8). Thus, we use the logarithm of the market value of equity instead of assets as a proxy for Size and the ratio of the market value of the firm to the book value of its assets as a proxy for Growth. The results (not reported here) of the regressions considering alternative variable definitions have implications on the Bath variable, which lost significance level (from $p$ $<0.01$ to $p<0.05$ ) in Models (7) and (8). In addition, they have also implications on the Size variable, which is no longer statistically significant in Models (6), (7) and (8).

Overall, the several sensitivity analyses conducted largely corroborate the results presented in Table 3 .

\section{SUMMARY AND CONCLUSIONS}

Since 1 January 2005 all public companies listed on regulated capital markets within the European Union, such as Euronext Lisbon, have been required to use IFRS as a basis for preparation of their consolidated financial statements. Consequently, since 1 January 2005 Portuguese companies listed on Euronext Lisbon have been required to use IAS 36, which deals with the impairment of non-financial fixed assets.

IAS 36 prescribes the procedures that a company should apply to ensure that its assets are carried at no more than their recoverable amount, namely the higher of the amount to be realised through use or sale of the asset. This standard aims at enhancing the usefulness of the information reported on financial statements. However, IAS 36 provides managers with considerable discretion about how to assess the true value of assets. Since the recoverable value is difficult to obtain objectively, assessing the magnitude of impairment loss may affect the reported profit. In fact, the subjectivity in applying an impairment test provides opportunities for management to manage earnings, which can lead to a distorted image in the financial statements that are provided to its users. There is significant evidence that the impairment of assets decision is influenced by managers (e.g. Beatty and Weber, 2006; Francis et al., 1996; Riedl, 2004; Spear and Taylor, 2011; Van de Poel et al., 2009). Summing up, it is expected that IAS 36 would reduce the magnitude and restrict the timing of reporting asset impairments. However, the decision of writing down the value of assets and the magnitude of impairment loss allows management of listed companies to exercise judgement in determining the recoverable value of assets, and provides a good chance for managers to opportunistically manage the reported earnings. Thus, this study investigates these two viewpoints and analyses the effect of IAS 36 on asset impairment reporting. It investigates whether IAS 36 reduces management's discretion over asset impairment magnitude and timing. Additionally, we also analyse the influence of audit quality on the use of the asset impairment test as a tool to manage earnings. Using a sample of 33 Euronext Lisbon non-financial firms over a period of nine years, from 2002 through 2010, we find that IAS 36 does not affect the magnitude of the reported asset impairment. This 
result is not surprising, since the IASB's approach in IAS 36 gives management substantial discretion about how to assess the true value (recoverable amount) of the firm's assets. We also find evidence that firms impair their assets more often when earnings are unexpectedly low or high. This suggests that impairment firms are engaging in either big bath or smoothing behaviour. Our results also suggest that firms audited by Big 4 firms take significantly more impairments than firms audited by non-Big 4 firms. This result seems to suggest that non-Big 4 auditors give firms more discretion to engage in income-increasing earnings management by postponing asset impairments. Additionally, the results shows that when there are incentives to under-report earnings, the likelihood of taking an asset impairment will increase more for firms audited by a non-Big 4 audit firm than for firms audited by a Big 4 audit firm.

Moreover, the results also reveal lower impairment loss when leverage is high, and higher impairment loss management during the crisis period and when firm size is high.

The findings of this study make the following contributions. First, the results appear to suggest that Portuguese listed firms use asset impairment as a tool to manage earnings. This result seems to suggest that IAS 36 does not contribute to improved financial reporting quality. Second, the findings are relevant for standard setters, suggesting that they should consider opportunities for earnings management in setting accounting standards, mainly in the case of the impairment of assets standard. Prevention of earnings management is needed to further ensure comparability of accounting numbers. Finally, investors may also benefit from the findings because they provide insight into the impact of IAS 36 and Big 4 audit firms on earnings quality.

This study has, however, some limitations. First, this study, similar to all asset impairment studies, uses the entire amount of the impairment rather than estimating the unexpected portion since the unexpected portion is unobservable. If some of the impairment is expected, using the entire impairment amount introduces measurement error, which causes biased and inconsistent estimates of the models' coefficients. Therefore, using the total impairment amount could limit the conclusions that are drawn from this study. Second, the reduced number of observations may influence some results, too. Nevertheless, this limitation is an immediate consequence of the small size of the Portuguese stock market. Third, we focus only on the consequences of a single accounting standard, and the overall effect on the quality of financial reporting will be the net consequence of applying many accounting standards. Finally, our sample is of listed companies of a single country, and further investigations using listed firms of other countries are necessary.

\section{NOTES}

The winsorisation method is considered quite good at identifying outliers in a normal sample (Hair, Anderson, Tatham and Black, 1998). 


\section{REFERENCES}

Alciatore, M., Dee, C.C., Easton, P. and Spear, N. (1998). Asset Write-Downs: A Decade of Research, Journal of Accounting Literature, Vol. 17, No. 5, pp. 1-39.

Andrews, R. (2006). Impairment of Assets: Measurement Without Disclosure?, research report no. 92, Leeds Metropolitan University, Certified Accountants Educational Trust, London.

Ball, R. (2006). International Financial Reporting Standards (IFRS): Pros and Cons for Investors, Accounting and Business Research, Vol. 36, Special Issue, pp. 5-27.

Balsam, S., Krishnan, J. and Yang, J.S. (2003). Auditor Industry Specialization and Earnings Quality, Auditing: A Journal of Practice E Theory, Vol. 22, No. 2, pp. 71-97.

Bartov, E. (1993). The Timing of Asset Sales and Earnings Manipulation, The Accounting Review, Vol. 68, No. 4, pp. 840-855.

Bartov, E., Lindahl, F.W. and Ricks, W.E. (1998). Stock Price Behavior Around Announcements of Write-Offs, Review of Accounting Studies, Vol. 3, No. 4, pp. 327-346.

Basu, S., Hwang, L. and Jan, C.L. (2002). Differences in Conservatism between Big Eight and Non-Big Eight Auditors, working paper, Baruch College, City University of New York.

Beatty, A. and Weber, J. (2006). Accounting Discretion in Fair Value Estimates: An Examination of SFAS 142 Goodwill Impairments, Journal of Accounting Research, Vol. 44, No. 2, pp. 257-288.

Becker, C.L., DeFond, M.L., Jiambalso, J. and Subramanyam, K.R. (1998). The Effect of Audit Quality on Earnings Management, Contemporary Accounting Research, Vol. 15, No. 1, pp. $1-24$.

Bini, M. and Bella, C.D. (2007). Determinants of Market Reactions to Goodwill Write-Off after SFAS 142, Managerial Finance, Vol. 33, No. 11, pp. 904-914.

Braun, K.W. (2001). The Disposition of Audit-Detected Misstatements: An Examination of Risk and Reward Factors and Aggregation Effects, Contemporary Accounting Research, Vol. 18, No. 1, pp. 71-99.

Cameron, A.B. and Stephens, L. (1991). The Treatment of Non-Recurring Items in the Income Statement and Their Consistency with FASB Concept Statements, Abacus, Vol. 27, No. 2, pp. 81-96.

Caneghem, T.V. (2004). The Impact of Audit Quality on Earnings Rounding-Up Behaviour: Some UK Evidence, European Accounting Review, Vol. 13, No. 4, pp. 771-786.

Caplan, J. and Harris, R. (2002). Coming into Focus, CFO Magazine, 1 January, Vol. 18, No. 1, pp. 53-54.

Chan, P., Ezzamel, M. and Gwilliam, D. (1993). Determinants of Audit Fees for Quoted UK Companies, Journal of Business, Finance and Accounting, Vol. 20, No. 6, pp. 765-785.

Chao, C.L. (2006). An Examination of SFAS No. 35: Adoption Timing Motives, Write-Off Characteristics, and Market Reaction, International Journal of Accounting Studies, Vol. 45, Special Issue, pp. 77-120.

Chen, K.C.W. and Lee, C.W.J. (1995). Executive Bonus Plans and Accounting Trade-Offs: The Case of the Oil and Gas Industry, 1985-96, The Accounting Review, Vol. 70, No. 1, pp. 91-111.

Chen, K.Y., Lin, K.L. and Zhou, J. (2005). Audit Quality and Earnings Management for Taiwan IPO Firms, Managerial Auditing Journal, Vol. 20, No. 1, pp. 86-104.

Chi, W., Lisic, L.L. and Pevzner, M. (2011). Is Enhanced Audit Quality Associated with Greater Real Earnings Management?, Accounting Horizons, Vol. 25, No. 2, pp. 315-335.

Chung, R., Firth, M. and Kim, J.B. (2003). Auditor Conservatism and Reported Earnings, Accounting and Business Research, Vol. 33, No. 1, pp. 19-32. 
Cohen, J., Krishnamoorthy, G. and Wright, A.M. (2004). The Corporate Governance Mosaic and Financial Reporting Quality, Journal of Accounting Literature, Vol. 23, pp. 87-152.

Dai, D., Mao, X. and Deng, F. (2007). A Research on Impairment of Assets in Listed Firms with Negative Earnings in China, Frontiers Business Research China, Vol. 1, No. 3, pp. 351-364.

DeFond, M.L. and Jiambalvo, J. (1994). Debt Covenant Violation and Manipulations of Accruals, Journal of Accounting and Economics, Vol. 17, Nos. 1-2, pp. 145-176.

Eckel, N. (1981). The Income Smoothing Hypothesis Revisited, Abacus, Vol. 17, No. 1, pp. 28-40.

Francis, J., Hanna, J.D. and Vincent, L. (1996). Causes and Effects of Discretionary Asset Write-Offs, Journal of Accounting Research, Vol. 34, Supplement, pp. 117-134.

Francis, J.R., Maydew, E.L. and Sparks, H.C. (1999). The Role of Big 6 Auditors in the Credible Reporting of Accruals, Auditing: A Journal of Practice and Theory, Vol. 18, No. 2, pp. 17-34.

Guidry, F., Leone, A. and Rock, S. (1999). Earnings-Based Bonus Plans and Earnings Management by Business Unit Managers, Journal of Accounting and Economics, Vol. 26, Nos. 1-3, pp. 113-142.

Gul, F., Lynn, S. and Tsui, J. (2002). Audit Quality, Management Ownership, and the Informativeness of Accounting Earnings, Journal of Accounting, Auditing and Finance, Vol. 17, No. 1, pp. 25-51.

Gul, F.A., Tsui, J. and Dhaliwal, D.S. (2006). Non-Audit Services, Auditor Quality and the Value Relevance of Earnings, Accounting and Finance, Vol. 46, No. 5, pp. 797-817.

Haron, N.H. and Atan, R. (2010). Goodwill Impairment - Earnings Management during the New FRS 3 Transitions: Evidence from the Main Board of Bursa Malaysia, Recent Advances in Business Administration, pp. 48-61.

Hair, J.F., Anderson, R.E., Tatham, R.L. and Black, W.C. (1998). Multivariate Data Analysis, fifth edition, Englewood Cliffs, NJ: Prentice Hall.

Healy, P.M. and Wahlen, J.M. (1999). A Review of the Earnings Management Literature and Its Implications for Standard Setting, Accounting Horizons, Vol. 13, No. 4, pp. 365-383.

Hirschey, M. and Richardson, V.J. (2002). Information Content of Accounting Goodwill Numbers, Journal of Accounting and Public Policy, Vol. 21, No. 3, pp. 173-191.

International Accounting Standards Board (1998). International Accounting Standard (IAS 36) on Impairment of Assets (revised), London: IASB.

Jahmani, Y., Dowling, W.A. and Torres, P.D. (2010). Goodwill Impairment: A New Window for Earnings Management?, Journal of Business E Economics Research, Vol. 8, No. 2, pp. 19-23.

Jensen, M.C. and Meckling, W.H. (1976). Theory of the Firm: Managerial Behavior, Agency and Ownership Structure, Journal of Financial Economics, Vol. 4, No. 3, pp. 305-360.

Jiang, W., Lee, P. and Anandarajan, A. (2008). The Association between Corporate Governance and Earnings Quality: Further Evidence Using the GOV-Score, Advances in Accounting Incorporating Advances in International Accounting, Vol. 24, No. 2, pp. 191-201.

Johl, S., Jubb, C.A. and Houghton, K.A. (2007). Earnings Management and the Audit Opinion: Evidence from Malaysia, Managerial Auditing Journal, Vol. 22, No. 7, pp. 688-715.

Jonhson, S. (2007). Fair Value Stumps Auditors, PCAOB Told, CFO Magazine, 21 June, available from: <http:/ /www.cfo.com/article.cfm/9388735>, accessed 16 August 2012.

Jordan, C.E. and Clark, S.J. (2004). Big Bath Earnings Management: The Case of Goodwill Impairment under SFAS No. 142, Journal of Applied Business Research, Vol. 20, No. 2, pp. 63-69.

Jordan, C.E., Clark, S.J. and Hames, C.C. (2010). The Impact of Audit Quality on Earnings Management to Achieve User Reference Points in EPS, Journal of Applied Business Research, Vol. 26, No. 1, pp. 19-30. 
Kinney, M. and Trezevant, R. (1995). Earnings Management Using Non-Recurring Items, working paper, Texas A\&M University.

Krishnan, G.V. (2003). Does Big 6 Auditor Industry Expertise Constrain Earnings Management?, Accounting Horizons, Vol. 17, Supplement, pp. 1-16.

Lemans, J. (2009). Goodwill Impairment as a Tool for Earnings Management, Master's thesis in Accounting, Auditing and Control, Faculty of Economics and Business, Erasmus University Rotterdam.

Li, J. and Lin, J.W. (2005). The Relation between Earnings Management and Audit Quality, Journal of Accounting and Finance Research, Vol. 13, No. 1, pp. 1-11.

Lin, J.W. and Hwang, M.I. (2010). Audit Quality, Corporate Governance, and Earnings Management: A Meta-Analysis, International Journal Auditing, Vol. 14, No. 1, pp. 57-77.

Lin, J.W., Li, J.F and Yang, J.S. (2006). The Effect of Audit Committee Performance on Earnings Quality, Managerial Auditing Journal, Vol. 21, No. 6, pp. 921-933.

McNichols, M., Wilson, G. and DeAngelo, L. (1988). Evidence of Earnings Management from the Provision for Bad Debts, Journal of Accounting Research, Vol. 26, Supplement, pp. 1-29.

Murphy, K. and Zimmerman, J. (1993). Financial Performance Surrounding CEO Turnover, Journal of Accounting and Economics, Vol. 16, Nos. 1-3, pp. 273-315.

Nelson, M.W. (2003). Behavioral Evidence on the Effects of Principles- and Rules-Based Standards, Accounting Horizons, Vol. 17, No. 1, pp. 91-104.

Nelson, M.W., Elliott, J.A. and Tarpley, R.L. (2002). Evidence from Auditors about Managers' and Auditors' Earnings-Management Decisions, The Accounting Review, Vol. 77, Supplement, pp. 175-202.

Nelson, M.W., Elliott, J.A. and Tarpley, R.L. (2003). How Are Earnings Managed? Examples from Auditors, Accounting Horizons, Vol. 17, Supplement, pp. 17-35.

Nelson, M.W., Smith, S.D. and Palmrose, Z.V. (2005). The Effect of Quantitative Materiality Approach on Auditors' Adjustment Decisions, The Accounting Review, Vol. 80, No. 3, pp. 897-920.

Pannese, D. and DelFavero, A. (2010). Fair Value Accounting: Affect on the Auditing Profession, Journal of Applied Business Research, Vol. 26, No. 3, pp. 43-50.

Pourciau, S. (1993). Earnings Management and Nonroutine Executive Changes, Journal of Accounting and Economics, Vol. 16, Nos. 1-3, pp. 317-336.

Rahman, R.A. and Ali, F.H.M. (2006). Board, Audit Committee, Culture and Earnings Management: Malaysian Evidence, Managerial Auditing Journal, Vol. 21, No. 7, pp. 783-804.

Rees, L., Gill, S. and Gore, R. (1996). An Investigation of Asset Write-Downs and Concurrent Abnormal Accruals, Journal of Accounting Research, Vol. 34, Supplement, pp. 157-169.

Riedl, E.J. (2004). An Examination of Long-Lived Asset Impairments, The Accounting Review, Vol. 79, No. 3, pp. 823-852.

Schipper, K. (1989). Commentary on Earnings Management, Accounting Horizons, Vol. 3, No. 3, pp. 91-102.

Sevin, S. and Schroeder, R. (2005). Earnings Management: Evidence from SFAS No. 142 Reporting, Managerial Auditing Journal, Vol. 20, No. 1, pp. 47-54.

Spear, N.A. and Taylor, A.M. (2011). Asset Write-Downs: Evidence from 2001-2008, Australian Accounting Review, Vol. 21, No. 56, pp. 14-21.

Strong, J. and Meyer, J. (1987). Asset Writedowns: Managerial Incentives and Security Returns, Journal of Finance, Vol. 42, No. 3, pp. 643-661.

Sun, J., Liu, G. and Lan, G. (2011). Does Female Directorship on Independent Audit Committees Constrain Earnings Management?, Journal of Business Ethics, Vol. 99, No. 3, pp. 369-382.

Sweeney, A. (1994). Debt Covenant Violations and Managers' Accounting Responses, Journal of Accounting and Economics, Vol. 17, No. 3, pp. 281-308. 
Alves

Tabachnick, B.G. and Fidell, L.S. (2001). Using Multivariate Statistics, New York, NY: Allyn \& Bacon.

Vafeas, N. (2005). Audit Committees, Boards, and the Quality of Reported Earnings, Contemporary Accounting Research, Vol. 22, No. 4, pp. 1093-1122.

Van de Poel, K., Maijoor, S. and Vanstraelen, A. (2009). IFRS Goodwill Impairment Test and Earnings Management: The Influence of Audit Quality and Institutional Environment, working paper, University of Antwerp, Maastricht University.

Watts, R.L. (2003). Conservation in Accounting Part I: Explanations and Implications, Accounting Horizons, Vol. 17, No. 3, pp. 207-221.

Watts, R.L. and Zimmerman, J.L. (1983). Agency Problems, Auditing and the Theory of the Firm, Some Evidence, Journal of Law and Economics, Vol. 26, No. 3, pp. 613-633.

Watts, R.L. and Zimmerman, J.L. (1986). Positive Accounting Theory, Englewood Cliffs, NJ: Prentice Hall.

Watts, R.L. and Zimmerman, J.L. (1990). Positive Accounting Theory: A Ten Year Perspective, The Accounting Review, Vol. 65, No. 1, pp. 131-156.

Yoon, S.S. and Miller, G.A. (2002). Cash from Operations and Earnings Management in Korea, International Journal of Accounting, Vol. 37, No. 4, pp. 395-412.

Zang, Y. (2008). Discretionary Behavior with Respect to the Adoption of SFAS No. 142 and the Behavior of Security Prices, Review of Accounting and Finance, Vol. 7, No. 1, pp. 38-68.

Zucca, L.J. and Campbell, D.R. (1992). A Closer Look at Discretionary Writedowns of Impaired Assets, Accounting Horizons, Vol. 6, No. 3, pp. 30-41. 